\title{
Public Diplomacy and Beijing City Image Research From Major International Sporting Events Perspective*
}

\author{
ZHANG Wei-wei \\ China Youth University of Political Studies, Beijing, China
}

\begin{abstract}
This paper focuses on Beijing as the host city for the major international sporting events and its influence on the city image building of Beijing. Major international sporting events are the key channels for the exchange and dissemination of information among athletes from various countries, media coverages, national and international audiences which involves interpersonal communication, organizational communication, and mass communication at all levels. At the same time, the volunteers, especially young volunteers (mostly college student volunteers) considered as the Beijing city spokesperson and also as a group of "public diplomacy ambassadors", transfer positive energy in international communication during major international sporting events. Therefore, major international sporting events held in Beijing play an irreplaceable role in the image building of the capital city of China, Beijing.
\end{abstract}

Keywords: city image, public diplomacy, college students

\section{Introduction}

In such a globalised world, the rise and fall of a country, the development of a country, and a country's strength lies not in ships and armaments, but depending on its political system, social spirit, core values, and its international appeal, in one word, in its soft power. Soft power is a concept developed by Joseph Nye (2012) of Harvard University to describe the ability to attract and co-opt rather than by coercion (hard power), using force or giving money as a means of persuasion. Soft power is the ability to shape the preferences of others through appeal and attraction. In 2012, Nye explained that with soft power, "the best propaganda is not propaganda", further explaining that during the Information Age, "credibility is the scarcest resource".

With China's rising status in the world, the international influence of China and the national image construction overseas are becoming more and more important. To try to avoid being shaped by other governments and the public to become their enemy, the most important strategy is to carry out public diplomacy. From the practical point of view, the current international environment for China's international image construction and the development of Chinese diplomacy is disadvantageous. China threat theory still exists and the media of our country in the international media communication is still weak. This makes the international image of China have been distorted by the mainstream Western media. The international environment is not good for China's overall diplomacy.

\footnotetext{
* Acknowledgements: This project was sponsored by "2016 Research Fund for the Research Innovation of Young Scholars" of China Youth University of Political Studies.

ZHANG Wei-wei, lecturer, Ph.D., School of Journalism and Communication, China Youth University of Political Studies.
} 
In recent years, China has actively carried out public diplomacy and showed a real China to the outside world, not only to create a favorable international environment for the country, but also for China to establish a good international image basis. The convergence of old and new media not only plays an important and irreplaceable role in the process of China to the world, but also promotes the development of China's foreign publicity work.

This paper is to explore how major international sporting events build on the international image of Beijing from a multi-dimensional communication. Referring to major international sporting events, it is related to multiple aspects, such as the host city (this project mainly refers to Beijing), athletes, volunteers, national and international media, and people from different countries to come to Beijing to watch the game.

Beijing, as the capital of the People's Republic of China, has successfully hosted the 2008 Summer Olympic Games. In the meantime, Beijing is the host city for 2022 Winter Olympic Games. These major international sporting events held and will be held in Beijing can provide the foreign audiences a better understanding of Beijing's development in politics, economy, technology and culture so on and so forth and can better enhance the image of the city of Beijing in international communication and promote the development of Beijing's foreign exchanges and cooperation.

This paper intends to research from a comprehensive perspective of journalism and communication, political science and sociology. College Students, especially those who play the role of volunteers in Beijing during major international sporting events, can be considered as "public diplomacy ambassadors" to enhance the image of the capital city of Beijing in the international arena. The paper will elaborate on the student volunteers' participation in the capital region during major international sporting events from the perspective of the student volunteers' public diplomacy awareness, public diplomacy literacy, and public diplomacy behavior as core variables to consider and explore the role of college student volunteers by relying on major international sporting events in the diffusion of public diplomacy and the impact on the college volunteers in other cities in China. Therefore, the paper will put forward the proposals for better play of the student volunteers' role in Beijing city's image construction in a series of following papers.

From a practical perspective, this paper will help give full play to the important role of student volunteers in the major international sporting events before, during, and after the games to enhance the image of the capital city of Beijing.

If the affinity of the international image of a certain country is a direct expression of its national cultural soft power, the international image of a city of affinity is a direct manifestation of the city's cultural soft power. A city's image, especially a country's capital city's image is crucial to the national image of this country. If the capital city's image in the eyes of international public opinion and citizens of other countries is not so good, either because of their own reasons or because of other reasons, which will make it difficult in the international arena. Beijing city's image has improved in recent years. Upgrading to further enhance the soft power of Beijing city is a major task and is fundamental to co-ordinate urban development and opening up.

Famous international American political scientist Joseph Nye said that the value of public diplomacy not only focuses on obtaining specific time-bound targets and there is now time to benefit all potential international affairs; it is to improve the essential part of a country's long-term strategic objectives and it makes foreign policy objectives through public diplomacy consolidate project information and comparative advantages of other soft power resources. 


\section{Taking the Australians' Perspective of Shanghai As an Example}

As Stephen FitzGerald (1997) stated it is not possible to have a fixed or unchanging view of China because it is not only a complex society and it is more a world than a country. The changing perceptions of Australians towards China reflect the confrontations between the Orient and Occident (Australia, although it is located in the Asia-pacific region, as Lachlan Strahan noted that Australia, settled by Europeans, overwhelmingly Christian (at least nominally), and based firmly on capitalist structures, was indelibly Western throughout 1930s to 1990s); socialism versus capitalism; communism in China versus the partyism in Australia. Pendulum paradigm is frequently seen as the explanatory model of Western perceptions of China. In terms of "Western" perceptions of China, Australia was the unmatched country that with its traditional origin from Britain and with the ideology westernisation and Australia's peripheral position in the West enabled it to adopt more flexible responses at times. On the other hand, Australia is geographically located in the Asia-Pacific region. Lachlan Strahan (1996a) stated that perceptions of China also reflected Australian reaction to "Asia" in general. Attitude remained unchanged while China changed. Particular images of China were generated by political, social, and economic conflicts in Australia. Sometimes China served as a screen onto which Australian preoccupations were projected. Some alternations in images expressed changes within Australia rather than in China, while shifts in intellectual traditions led to reappraisals (Strahan, 1996b).

\section{Shanghai-Image of China}

Shanghai has long been a potent symbol in Australian representations of China and it is often reread as a text when there have been shifts of Australian perceptions of China. In other words, changes in the Australian perceptions of Shanghai reflected those with that of China, and vice versa. Shanghai has been embedded with images as the Paris of the East, the city of swing and sin, the Oriental Babylon, a ghost town, an enslaved city of lost glory, or the beacon of the "New Jerusalem" (Strahan, 1996c). In 1993, Ross Peake, a journalist in Keating's press party, wrote in the Canberra Times, on 28 June 1993:

The rapid economic growth that is coursing though China bubbles to the surface in the vibrant southern city of Shanghai. The huge city, which houses the equivalent of the entire Australian population, is bursting with energy and noisy with trade. (Peake, 1993)

Michael Millett, a journalist with Keating delegation to China, argued in Sydney Morning Herald on 26 June 1993 that China is "an economic dragon finally prodded into action by the reform programs of DENG Xiao-ping". Shanghai is in "the mouth of the Chinese dragon".

Lachlan Strahan (1996d) expressed his opinion that Australian reactions to China in the mid-1990s reproduced old ambivalences. On the one hand, China is an indispensable element to Australia, on the other hand, China is still perceived as a military and economic threat. David Lague, a reporter of China for Murdoch and Fairfax newspapers, was quite pessimistic of China's rapid economic developments, especially the problems like unemployment, imbalance across China, and unsustainability. Malcolm Booker, former diplomat and columnist for the Canberra Times, maintains that China is in danger of economic crisis, popular rebellion, and perhaps even disintegrating.

As Professor David Carter (2006) wrote in his book Dispossession, Dreams \& Diversity: Issues in Australian Studies, Australian's distance from the "mother country" heightened a feeling of isolation and vulnerability. These responses directly influenced economic, social, and defensive policies in Australia as well 
as individual attitudes. To certain extent, such feelings make some Australians sensitive towards its so-called potent attack from the neighbouring countries in the region and especially that from China. The perception of China as a military threat was to some extent a reaction to the end of the Cold War. Just as David Lague (1992) asserted on 14 October 1992 in The Australian that "There are fears that the end of the Cold War has opened a vacuum that Beijing will be unable to resist" (Lague, 1992). Prime Minister Paul Keating addressed the Royal United Services Institute in Canberra on 22 September 1994 and said China was the strongest country in Asia and central to the region's security and Australia should help China find a place for itself (Strahan, 1996e). In late June 1995, the second conference on Australia-China Relations was held at Griffith University and the consensus from the conference was that China is most unlikely in the foreseeable future to adopt an aggressive military posture towards its neighbours, let alone send in troops to take over their governments.

In Senator John Button's 1985 visit to China, he said that per capita, Australia provided the largest number of tourists from any other overseas country to China and he considered this was a tribute to the history of the bilateral relations. His visit to China was so impressive that after his return to Australia, he concluded in his speech "Reflections on a Recent Visit to China" to the first conference on Australia-China Relations held at Griffith University in 1985, "I stress the importance of handling the relationship carefully because it is a very important one and we do not want it destroyed". He asserted that, "I drew a few conclusions from my visit there and I came back resolved as far as I can to try and improve the relationship with China in every walk of life in Australia". The difference between the official high-level visits and the individual travels to certain foreign country is that the former's impression sometimes directs their political relations and as decision-maker with certain diplomatic policies might base on this. These policies could influence the citizens' perceptions of other countries. However, the latter would largely stay as personal experiences.

Throughout the nineteenth and twentieth centuries, Australians knew or thought they knew a great deal about China. China loomed large always in the Australian imagination. But at the same time, through most of those two centuries, the proportion of that knowledge drawing on empirical observation directly on people who had seen China first hand was very small indeed. (White, 2008a)

This was stated by Richard White (2008a), a senior lecturer of history at the University of Sydney, in his journal article Australian Journalists, Travel Writing and China: James Hingston, the "Vagabond" and G.E. Morrison. The perspective of Richard White was somehow different from other journalists, academics, politicians, and the media commentators and to certain extent because his research focuses on history of travel and tourism. In other words, there are few people-to-people contacts between Australians and the Chinese, while much of the Sino-Australian cooperation orientated at economy both on the governmental and non-governmental levels in the past two decades. He puts forward that until recent years China has become a significant travel destination to Australia and henceforth an imbalance between a superfluity of "theoretical" knowledge and limited first-hand experience in terms of China of the Australian imagination exists (2008b). Travelling also led to the reassessment of old notions in relation with China, which is an alien culture in some Australians' eyes. The direct contact and personal experience in China provided them with more information that seemed impossible to acquire when looking China from the outside. On the contrary, more and more Australians came face to face with China and strove to come to terms with Chinese in a rapidly changing world where old certainties were disappearing. 


\section{Conclusion}

The rapid increase in the number and variety of international sporting competitions over the past 50 years has seen "the increase in people-to-people exchanges, both virtual and personal, across national borders". The communicative power of international sport has increased dramatically by the information and communications technologies revolution over the past several decades, enabling the audience for major sporting events to expand to hundreds of million people (Pigman, 2014).

Principal part of public diplomacy is diversified with Western countries only considering the public as a public diplomacy receptor and China's public diplomacy receptor mainly relies on non-governmental forces, and other social organizations, research institutes, enterprises, and even individuals that are able to have the opportunity to engage in international exchanges and dialogue organizations. On 4 May 2013, when President XI Jin-ping (2013) gave a speech to outstanding youth representatives, he said that Chinese Dream is national and ethnic and belongs to every Chinese. Chinese Dream is our dream and it is also the younger generation's dream. Great rejuvenation of the whole nation will eventually make it into reality in the relay of the majority of young people.

ZHAO Qi-zheng (2011) said, "In the long run, the exchange and communication of young people is important. Because your exchange and communication has just become mature and that can maintain for decades, so we are in the hands of young people's communication".

Every Chinese represents the image of the China and is the principal representative of public diplomacy. China is a large book and has 1.3 billion pages thick that each Chinese is one page. Foreigners could not read the entire book and may read only three or five pages and then these three or five people could be the image of the entire Chinese people in their eyes. The practice of Chinese dream has been proved to be long and on the one hand, Chinese people should have self-confidence; on the other hand, Chinese people should understand that each person himself shoulders responsibility, so as to better integrate into the world.

In recent years, China has actively carried out the public diplomacy to present and explain to the outside world a true China, not only for our country to create a favorable international public opinion environment, but also for the international image of our country to set a good foundation. The convergence of old and new media not only plays an important and irreplaceable role in the process of China to the world, but also promotes the development of China's foreign publicity work.

\section{References}

Carter, D. (2006). Dispossession, dreams \& diversity : Issues in Australian studies (p. 280). Frenchs Forest, N.S.W: Pearson Education.

Dunn, H. A., \& Edmund, S. K. F. (Eds.). (1985). Sino-Australian relations: The record 1972-1985 (p. 16). Brisbane: Griffith University.

FitzGerald, S. (1997). Is Australia an Asian country? Can Australia survive in an East Asian future? (p. 34). St. Leonards, N.S.W: Allen \&Unwin.

Mackerras, C. (Ed.). (1996). Australia and China: Partners in Asia (p. 206). South Melbourne: Macmillan Education Australia.

Nye, J. (2012). Retrieved from https://en.wikipedia.org/wiki/Soft_power

Pigman, G. (2014). International sport and diplomacy's public dimension: Governments, sporting federations and the global audience. Diplomacy \& Statecraft, 25, 94.

Strahan, L. (1996a). Australia's China: Changing perceptions from the 1930s to the 1990s (p. 13). Cambridge: Cambridge University Press.

Strahan, L. (1996b). Australia's China: Changing perceptions from the 1930s to the 1990s (p. 10). Cambridge: Cambridge 
University Press.

Strahan, L. (1996c). Australia's China: Changing perceptions from the 1930s to the 1990s (p. 300). Cambridge: Cambridge University Press.

Strahan, L. (1996d). Australia's China: Changing perceptions from the 1930s to the 1990s (p. 317). Cambridge: Cambridge University Press.

Strahan, L. (1996e). Australia's China: Changing perceptions from the 1930s to the 1990s (p. 319). Cambridge: Cambridge University Press.

Strahan, L. (1996f). Australia's China: Changing perceptions from the 1930s to the 1990s (p. 320). Cambridge: Cambridge University Press.

White, R. (2008a). Australian journalists, travel writing and China: James Hingston, the "Vagabond" and G.E.Morrison. Journal of Ausralian Studies, 32(2), 238.

White, R. (2008b). Australian journalists, travel writing and China: James Hingston, the "Vagabond" and G.E. Morrison. Journal of Ausralian Studies, 32(2), 237.

XI, J. P. (2013). Retrieved from http://news.xinhuanet.com/politics/2013-05/04/c_115639203.htm

ZHAO, Q. Z. (2011). Retrieved from http://news.xinhuanet.com/politics/2011lh/2011-03/05/c_121152591.htm 